\title{
Haksız Rekabette İhtiyati Tedbir Uygulamaları ve Özellik Arz Eden Durumlar (TTK m. 61)
}

\author{
Precautionary Measures in Unfair Competition and Special Situations \\ (TCC art. 61)
}

\section{Abdüssamet Yılmaz ${ }^{*}$ (ID}

\section{öz}

Haksız rekabet uygulamasında ihtiyati tedbir kurumunun ayrı bir yeri ve önemi vardır. Bu nedenledir ki kanun koyucu TTK m. 61'de ayrı bir ihtiyati tedbir hükmü düzenlemiştir. Maddede yer alan ihtiyati tedbir türleri incelendiğinde, bunların ifa amacına yönelik olduğu görülmektedir. İfa amaçlı ihtiyati tedbirlerin haksız rekabet hukukunun amacı ve koruduğu menfaatler ile uyumlu olduğu belirtilmelidir. Zira haksız rekabete konu haklar genellikle kısa ömürlü olup, uzun süren davaları kaldıramayacak kadar geçici niteliktedirler. Bu itibarla tedbir taleplerinin ifa amacına yönelmesi özellikle haksız rekabet eyleminden zarar gören tarafın haklarının korunması noktasında büyük bir önemi haizdir. İhtiyati tedbir şartları bakımından ise HMK hükümleri uygulanacak olup, bunların da haksız rekabet yargılamasının özellikler göz önünde bulundurularak mahkemelerce uygulanması önemlidir.

Anahtar Kelimeler: Haksız rekabet, ihtiyati tedbir, ifa amaçlı ihtiyati tedbir.

\section{ABSTRACT}

The precautionary measures has a great place in unfair competition law. For this reason, the legislator regulated this institution with a separate provision in art 61 of TCC. When the types of precautionary measures in the article are examined, it is seen that they coincide with the decisions to be made as a result of the court. Considering the purpose of unfair competition law and the interests it protects, it should be noted that this approach is correct. Because the rights subject to unfair competition are generally short-lived, and they are too temporary to handle long-lasting lawsuits. In this respect, it is of great importance that the interim injunctions are directed to the purpose of performance, especially in terms of protecting the rights of the party injured by the act of unfair competition. In terms of interim injunction conditions, the provisions of the CCP will be applied, and it is important that these are applied by the courts, taking into account the peculiarities of unfair competition proceedings.

Keywords: Unfair competition, precautionary measures, interim injunction.

* $\quad$ Ar. Gör. Dr., Marmara Üniversitesi Adalet MYO, Ticaret Hukuku, ORCID: 0000-0003-4496-0372.

Sorumlu Yazar/Correspondence Author: Abdüssamet Yilmaz

E-posta/E-mail: abdussamet.yilmaz@marmara.edu.tr

Geliş Tarihi/Received: $\quad 15.09 .2021$

Kabul Tarihi/Accepted: $\quad$ 23.11.2021 


\section{GiRiş}

Haksız rekabet hukuku 6102 sayılı Türk Ticaret Kanunu’nun (TTK) 54 ilâ 63. maddeleri arasında düzenlenmektedir. TTK m. 54/I'de kurumun amacı, bütün katılanların menfaatine, dürüst ve bozulmamış rekabet ortamının temini olarak açıklanmış olup bütün katılanlardan kasıt ise gerekçede de ifade edildiği üzere ekonomi, tüketici ve kamu üçlüsüdür ${ }^{1}$. Haksız rekabet hukuku hükümleri ile rekabet ortamının düzgün işleyişi amaçlandığından, dürüst rekabet ortamını bozucu nitelikteki eylemlerin durdurulmasında, yukarıda sayılan “üçlü”nün önemli menfaati bulunmaktadır.

Ülkemizde yargılama sürelerinin uzunluğu haksız rekabetten kaynaklı uyuşmazlıklar bakımından da sakıncalı sonuçlar doğurmaktadır. Zira yargılamanın uzaması, haksız rekabet sebebiyle oluşan zararın artmasına ve giderek tazmini imkansız hale gelmesine neden olmaktadır. Haksız rekabet sebebiyle uğranılan zararın miktarının belirlenmesinin de çoğu zaman mümkün olmadığı göz önünde bulundurulduğunda ${ }^{2}$, uzayan yargılama süreleri sorunu çok daha vahim bir hale getirmektedir. Örneğin kötüleme haksız rekabet eyleminin mevcudiyeti durumunda, söz konusu eylem nedeniyle ortaya çıkan zarar her zaman net bir şekilde ortaya konulamamaktadır. Tarafların ticari defterlerinin incelenmesi de bu konuda yol gösterici olmamakta, bir zararın oluştuğu ortaya konulsa bile bu sefer haksız rekabet eylemi ile zarar arasındaki illiyet bağının kurulmasında problemlerle karşılaşılmaktadır. Bu da eylemden zarar görenin tazminata ulaşmasını zorlaştırmaktadır. Davanın sonuna kadar bu eylemin etkilerinin devam etmesi ise davacının zararlarını katlanılmaz boyutlara ulaştırabilmektedir. Haksız rekabet yargılamasında ortaya çıkabilecek bu gibi sakıncalar, ihtiyati tedbir müessesesine ayrı bir önem kazandırmaktadır. Zira ihtiyati tedbir talebi, dava sonunda verilecek olan hükmün icrasının mümkün olmaması veya çok güçleşmesi tehlikelerine karşı getirilen bir geçici hukuki koruma müessesesidir ${ }^{3}$. Bu itibarla dava sonunda verilecek olan kararın icrasının güvence altına alınması ihtiyati tedbirin en önemli işlevlerinden biri olarak karşımıza çıkmaktadır.

Çalışmamız kapsamında, ihtiyati tedbir kurumunun haksız rekabet hukuku bağlamında özellik arz eden yönleri üzerinde durulacaktır. Bu bağlamda ihtiyati tedbirin şartları ile ihtiyati tedbir türlerinin haksız rekabet uyuşmazlıklarındaki görünümleri incelenecektir.

\section{HAKSIZ REKABET HUKUKUNDA IHTIYATI TEDBIR KURUMUNUN DÜZENLENIŞ ŞEKLi}

İhtiyati tedbir kurumu esas itibariyle 6100 sayılı Hukuk Muhakemeleri Kanunu'nun (HMK) 389 vd. maddelerinde düzenlenmiştir. Bunun yanında çalışmamız kapsamında incelemeye tabi tutulacak olan TTK m. 61'de de haksız rekabet hukuku özelinde ihtiyati tedbir düzenlemesine yer verilmiştir ${ }^{4}$.

6102 sayılı Türk Ticaret Kanunu Madde Gerekçesi, m. 54.

2 Anne-Christine Fornage and Isabelle Chabloz, 'Remarques Liminaires Aux Articles 9 a 11 LCD' in Vincent Martenet and Pascal Pichonnaz (eds), Commentaire Romand (Helbing Lichtenhahn, 2017) 402.

3 Muhammet Özekes 'Geçici Hukuki Koruma’ iç Hakan Pekcanıtez (edr) Medeni Usul Hukuku (Oniki Levha 2017) 2461; Muhammet Özekes 'Fikir ve Sanat Eserleri Hukukunda İhtiyati Tedbir' (2002) 4(2) Dokuz Eylül Üniversitesi Hukuk Fakültesi Dergisi 89, 90.

4 Bu düzenleme, TTK’nın haksız rekabet hükümleri bakımından mehaz teşkil eden Haksız Rekabete Karşı Federal 
İhtiyati tedbir kurumunun haksız rekabet uygulamasındaki önemi ve özellikle tedbir taleplerinin türü bakımından sahip olduğu farklılıklar nedeniyle kurumun ayrı bir maddede düzenlenmesi gereği doğmuştur.

\section{A. HAKSIZ REKABET HUKUKUNDA IHTIYATI TEDBIRE ILIŞKIN ÖZEL DÜZENLEME}

6102 sayılı Türk Ticaret Kanunu’nun 61. maddesi “İhtiyati Tedbirler” kenar başlığını taşımaktadır. Hükmün ilk fıkrası, "Dava açma hakkını haiz bulunan kimsenin talebi üzerine mahkeme, mevcut durumun olduğu gibi korunmasına, 56 ncı maddenin birinci fikrasinin (b) ve (c) bentlerinde öngörüldüğ̈̈ gibi haksız rekabet sonucu oluşan maddi durumun ortadan kaldırlmasına, haksız rekabetin önlenmesine ve yanlışveya yanıltıcı beyanların düzeltilmesine ve diğer tedbirlere, Hukuk Usulü Muhakemeleri Kanununun ihtiyati tedbir hakkındaki hükümlerine göre karar verebilir." şeklindedir.

Maddeden anlaşıldığı üzere kanun koyucu haksız rekabet teşkil eden bir eylem sebebiyle zarar gören veya zarar tehlikesine maruz kalan bir kişinin ihtiyati tedbir talebinde bulunabileceğini ifade etmekte ve talep edilebilecek ihtiyati tedbir türlerine ilişkin de bir belirleme yapmaktadır. TTK m. 61 'de hüküm bulunmayan hallerde ise HMK m. 389 vd. hükümlerinin uygulanacağ 1 yine maddeden anlaşılmaktadır ${ }^{5}$. Bu kapsamda ilk olarak maddede belirtilen ihtiyati tedbir türleri üzerinde durulacak, ardından haksız rekabetten kaynaklı uyuşmazlıklarda ihtiyati tedbir talebinde bulunulabilmesi için gereken şartlar değerlendirilecektir.

\section{IHTIYATI TEDBIR TÜRLERI}

TTK m. 61'de esas itibariyle ihtiyati tedbir türleri üzerinde durulmaktadır. Gerçekten de kanun koyucu bu maddede, hangi tür tedbir talebinde bulunulabileceğini belirlemiş, ihtiyati tedbirin şartları bakımından da HMK hükümlerine yollama yapmıştır. Madde kapsamında haksız rekabet eylemi dolayısıyla dava açma hakkına sahip olan kimse mahkemeden şu ihtiyati tedbir taleplerinde bulunabilir:

- Mevcut durumun olduğu gibi korunması,

- Haksiz rekabetin men'i,

- Haksız rekabet sonucu oluşan durumun ortadan kaldırılması,

- Haksız rekabetin önlenmesi,

- Yanlış veya yanıltıcı beyanların düzeltilmesi,

Kanun'da (Loi Federal Contre la Concurrence Deloyale) yer almayan bir maddedir. İsviçre uygulamasında haksız rekabet sebebiyle ihtiyati tedbir talepleri ayrı bir maddede düzenlenmediğinden, İsviçre Medeni Usul Kanunu’nun ilgili hükümleri (Code de Procédure Civile) haksız rekabet uyuşmazlıklarında da uygulama alanı bulmaktadır, bkz. Fornage and Chaloz (n 1) $400 \mathrm{vd}$.

5 N. Füsun Nomer Ertan, Haksız Rekabet Hukuku (Oniki Levha 2016) 469. 
- Diğer tedbirler,

- Gümrük idareleri tarafından el konulma.

Kanun koyucunun TTK m. 61/I'de "diğer tedbirler" demek suretiyle ihtiyati tedbir türlerini burada sayılanlarla sınırlamadığı, hâkime bu konuda geniş bir takdir yetkisi verdiği anlaşılmaktadır. Bu itibarla hâkim gerek görürse HMK'da yer verilen ihtiyati tedbir türlerine de karar verebilecektir ${ }^{6}$.

Maddede yer verilen ihtiyati tedbir türleriyle ilgili dikkat çeken bir diğer husus da kanun koyucunun TTK m. 56'da yer alan haksız rekabet sebebiyle açılacak davalardaki taleplerden birebir alıntı yapmasıdır. Gerçekten de TTK m. 61'de, TTK m. 56/1, b ve c hükümlerinin tekrar edildiği görülmektedir7. Burada önemli bir sorun olarak, dava neticesinde verilecek bir sonuca aslında ihtiyati tedbir kararı ile ulaşılması gündeme gelmektedir. Bu ise ihtiyati tedbir türlerinin içerik itibariyle davanın esasını çözer mahiyette olması, dava sonuçlanmadan ve hatta asıl dava açılmadan, dava sonucunda varılacak sonuca ulaşılması sonucunu doğurmaktadır.

Bilindiği üzere ihtiyati tedbir kurumunun geçici niteliği, taraf menfaatleri arasındaki dengenin sağlanmasını zorunlu kılmaktadır ${ }^{8}$. İhtiyati tedbir kurumu, talepte bulunanı tatmin etme amacını taşımadığı gibi dava sonucunda verilmesi muhtemel bir kararın ihtiyati tedbir kararı ile verilmesi, bu sayede uyuşmazlığın esasının zamanından önce çözümlenmesi de mümkün değildir ${ }^{9}$. Bu husus İstanbul Bölge Adliye Mahkemesi 12. Hukuk Dairesi tarafından verilen kararda10, "Davacının nihai talebi ile ihtiyati tedbir talebi çakışmakta olup, davanın sonunda verilecek hükmün, ihtiyati tedbir yolu ile verilmesi mümkün değildir. Davalının haksız rekabet teşkil ettiği öne sürülen davranışlarda bulunduğu yargılama ile belirlenirse, bunların tespitine ve men'ine yargılama sonunda karar verilebilecektir." şeklinde ifade edilmiştir ${ }^{11}$. Buna rağmen haksız rekabetten kaynaklı uyuşmazlıklarda doğrudan davanın esasına yönelik kararların ihtiyati tedbir yoluyla da verilmesi mümkündür. Kanun koyucunun bu tercihi, haksız rekabet teşkil eden eylemlerin niteliğinden ve rekabet ortamının düzgün

6 Engin Erdil, Haksız Rekabet Hukuku (Seçkin 2020) 446.

7 Belirtmek gerekir ki maddenin kaleme alınış tarzında birtakım hatalar da bulunmaktadır. Şöyle ki, ilk olarak TTK m. 56/I, b’de haksız rekabetin men'i kavramı kullanılmışken, TTK m. 61/I’de hem TTK m. 56/I, b’ye atıf yapılmış hem de ayrıca haksız rekabetin önlenmesinden bahsedilmiştir. İkinci olarak ise maddede açıkça TTK m. 56/I, c’ye atıf olmasına rağmen ayrıca bu maddenin tekrardan yazımı yoluna da gidilmiştir. Bu iki husus maddenin kaleme alınışındaki özensizliği göstermesi itibariyle önemlidir.

8 "Hukuk yargılamasının amacının, doğru ve adil karar vermek olduğu, hak kaybının davanın her iki tarafı için de gözetilmesi gerektiğ $i$, us $\hat{l}$ kurallarının davanın her iki tarafının da haklarını korumak, kararın adaletli olmasını sağlamak ve davanın tarafları arasındaki uyuşmazlı̆̆ı çözerken her iki tarafı da aynı oranda korumak için getirildiğini (...)” HGK, 18.1.2012, 2011-13/701 E. 2012/6 K. (Kazancı İçtihat Bilgi Bankası).

9 Nevhis Deren Yıldırım, Haksız Rekabet Hukuku ile Fikri ve Sinai Mülkiyet Hukukunda İhtiyati Tedbirler (Alkım 1999) 9; Derya Keskinci, 'Haksız Rekabet Yargılama Hukukunda İfa Amaçlı İhtiyati Tedbirler' (2013) 2(2) Zirve Üniversitesi Hukuk Fakültesi Dergisi 145, 147; Nomer Ertan (n 5) 471; Müjgan Tunç Yücel, 'Haksız Rekabet Hukukunda Teminat Amaçlı İhtiyati Tedbirler' iç Prof. Dr. Ergun Önene Armağan (Alkım 2003) 420-421.

10 İstanbul BAM 12 HD, E 2018/715 K 2018/833, 28.06.2018 (R. Tamer Pekdinçer ve Ozan Ali Tok, İsviçre Hukuku ile Mukayeseli Türk Haksız Rekabet Hukuku Mevzuatı, (Seçkin 2019) 255-256).

11 Ayrıca bkz. Yargitay 13. HD, E 2012/2615 K. 2012/7420, 21.03.2012 (Kazanc1 içtihat bankas1) “... hakimin ....ihtiyati tedbir konulmasına karar verilmiş davanın ve uyuşmazlı̆̆ın esasini halleder şekilde ihtiyati tedbir kararı verilmesi HMK'nu 394/5'ne aykiri olup bozmayı gerektirir." 
işlemesine olan kolektif menfaatin varlığından kaynaklanmaktadır. Nitekim doktrinde, ihtiyati tedbirlerin teminat amacı yanında ifa amaçlı olarak da tesis edilebileceği kabul edilmektedir ${ }^{12}$. TTK m. 61 düzenlemesi de bu konudaki en önemli örneklerden biri olarak karşımıza çıkmaktadır.

İfa amaçlı ihtiyati tedbirlerde amaç, ihtiyati tedbir talebinde bulunanın hakkına, dava sonuçlanmadan kısmen veya tamamen ulaşmasıdır. Dolayısıyla bu tedbirler hakkı temin etmenin ötesinde, alacaklının geçici olarak tatminine de hizmet etmektedir ${ }^{13}$. Haksız rekabet hukukunda korunan menfaatler göz önünde bulundurulduğunda ifa amaçlı ihtiyati tedbir türlerinin uygulanmasının önemi ortaya çıkacaktır. Zira haksız rekabet eylemi sebebiyle hakları ihlal edilen kişinin, bu eylemin etkilerinin ortadan kaldırılmasında acil bir menfaati bulunmaktadır. Elbette verilecek tedbir kararında taraf menfaatlerinin gözetilmesi ve bir dengenin kurulması, ifa amaçlı ihtiyati tedbirlerin ağırlığı nedeniyle daha da önem taşımaktadır.

Aşağıda ihtiyati tedbir talebinde bulunmanın şartları üzerinde durulacak ve meselenin haksız rekabet hukuku boyutuyla ilgili açıklamalarda bulunulacaktır. Özellikle ifa amaçlı ihtiyati tedbir kararı verilmesinin mevcut sistemdeki sonuçları üzerinde durularak çözüm önerileri getirilmeye çalışlacaktır.

\section{IHTIYATI TEDBIR TALEBINDE BULUNMANIN ŞARTLARI}

TTK m. 61'de ihtiyati tedbire karar verilebilmesi için gereken şartlar üzerinde durulmamış, bunun yerine doğrudan HMK hükümlerine atıfta bulunulmuştur. Bu sebeple haksız rekabet uyuşmazlıklarında ihtiyati tedbir kararı HMK m. 389 vd. uyarınca verilecektir.

HMK m. 389/I düzenlemesinde, ihtiyati tedbir talebine ilişkin genel bir ihtiyati tedbir şart1, "Mevcut durumda meydana gelebilecek bir değişme nedeniyle hakkın elde edilmesinin önemli ölçüde zorlaşacağından ya da tamamen imkânsız hale geleceğinden veya gecikme sebebiyle bir sakıncanın yahut ciddi bir zararın doğacağından endişe edilmesi hallerinde, uyuşmazlik konusu hakkında ihtiyati tedbir kararı verilebilir." şeklinde belirlenmiştir. HMK m. 390/III düzenlemesinde ise "Tedbir talep eden taraf, dilekçesinde dayandiğı ihtiyati tedbir sebebini ve türünü açıkça belirtmek ve davanın esası yönünden kendisinin haklilı̆̆ın yaklaşık olarak ispat etmek zorundadır." denilerek hem ihtiyati tedbir talebinde bulunulabilmesinin bir diğer şartı ortaya konulmuş hem de ihtiyati tedbir yargılamasında uyulması gereken kurallardan, yaklaşık ispat kuralı ifade edilmiştir. Her iki hükümden hareketle, geçici bir hukuki koruma niteliğinde olan ihtiyati tedbir talebinde bulunulabilmesi için temel olarak iki şartın mevcut olması gerektiği görülmekte olup bunlar, ihtiyati tedbire esas bir hakkın bulunması ile ihtiyati tedbir sebebinin mevcut olması olarak karşımıza çıkmaktadır ${ }^{14}$.

12 Bkz. Deren Yildırım (n 9) 10; Keskinci (n 9) 147.

13 Keskinci (n 9) 148.

14 Özekes, Medeni Usul Hukuku (n 3) 2463; Baki Kuru, Ramazan Arslan ve Ejder Yllmaz, Medeni Usul Hukuku (Yetkin 2013) 559; Ramazan Korkmaz, Haksı İhtiyati Tedbir ve İhtiyati Hacizden Kaynaklanan Tazminat Davası (Oniki Levha 2020) 160 . 


\section{A. IHTIYATI TEDBIRIN HAK UNSURUNUN HAKSIZ REKABET HUKUKUNDA GÖRÜNÜMÜ}

İhtiyati tedbir talebinde bulunulabilmesi için talepte bulunanın gerçekten bir hakka sahip olması gerekmektedir. Zira dava sonunda sahip olunamayacak bir hakkın ihtiyati tedbir ile sağlanması mümkün değildir. Haksız rekabetten kaynaklı uyuşmazlıklarda da ihtiyati tedbirin hak unsurunu, talepte bulunanın haksız rekabet hükümleri ile korunan menfaati oluşturmaktadır. Bu menfaat her bir haksız rekabet eylemine göre farklılık arz edecektir. Örneğin talepte bulunanın bir iş ürününden karşı tarafça yetkisiz yararlanılmışsa (TTK m. 55/I,c), söz konusu iş ürünü üzerinde, haksız rekabet hükümleri ile sağlanan koruma hakkı kapsamında talepte bulunanın geçerli bir hakkı bulunduğu kabul edilecektir. Benzer bir şekilde bir kötüleme haksız rekabet halinin mevcut olduğu durumda (TTK m. 55/I,a-1) talepte bulunanın itibarı zedelenmekte ve ihtiyati tedbire konu hak da haksız rekabet eylemi ile zedelenen ve dolayısıyla koruma altında bulunan bu itibar olmaktadır. Bir diğer örnek olarak karıştırılmaya yol açan önlemler almanın söz konusu olduğu hallerde (TTK m. 55/ I,a-4) talepte bulunanın ürünleri veya faaliyetleriyle karıştırılmaya neden olacak eylemler, bu kişinin emeğinden haksız yararlanılmasına sebep olacağından, söz konusu emek ihtiyati tedbirin hak unsurunu oluşturacaktır. Görüldügü üzere TTK m. 55'de sayılan hallerden birinin gerçekleştiği durumlarda esasında haksız rekabet hükümleri ile korunan bir menfaat söz konusu olduğundan, eylemin mevcudiyetinin ortaya konulması, ihtiyati tedbire karar verilmesi için gereklidir.

\section{B. IHTIYATI TEDBIR SEBEPLERININ HAKSIZ REKABET HUKUKUNDA GÖRÜNÜMÜ}

İhtiyati tedbir talebinde bulunulabilmesinin bir diğer şartını ise, ihtiyati tedbir sebeplerinin bulunması oluşturmaktadır. İhtiyati tedbir sebepleri HMK m. 389/I'de genel bir çerçeve verilmek suretiyle belirlenmiştir. Buna göre ihtiyati tedbir talebinde bulunulabilmesi için hakkın elde edilmesinin önemli ölçüde zorlaşması ya da tamamen imkânsız hale gelmesi veya gecikme sebebiyle bir sakıncanın yahut ciddi bir zararın doğması endişelerinin bulunması gerekmektedir. Talepte bulunanın bu hususları da yaklaşı ispat ölçüsünde ispatlaması gerekmektedir ${ }^{15}$.

Haksız rekabet hukukunda korunan haklar göz önünde bulundurulduğunda, davanın nihayete ermesinin beklenmesi ve bu sürede haksız rekabet eyleminin sonuçlarının devam etmesi telafisi mümkün olmayan zararlara neden olabilecektir. Örneğin sosyal medya platformları üzerinden gerçekleştirilen kötüleme haksız rekabet eyleminde, söz konusu beyanlar ilgili sosyal medya platformlarında kaldığı sürece etkilerini göstermeye devam edecektir. Bu halde, yargılamanın da uzun sürmesi sebebiyle tüketiciler nezdinde oluşacak algının geri döndürülmesi zorlaşacaktır. İşletmenin kötüleme öncesi itibarına ulaşması için harcayacağı emek ve zaman da göz önünde bulundurulduğunda, zararının artmaya devam edeceği ve çoğu zaman telafisinin de mümkün olmayacağı sonucuna varılabilecektir. Ya da iş ürününden yetkisiz yararlanma haksız rekabet

15 Korkmaz (n 14) 179. Ayrica bkz. Yargitay Hukuk Genel Kurulu, E 2014/14-1587 K 2016/822, 22.06 .2016 (Kazanc1 Veritaban1), "Ihtiyati tedbir talep eden taraf, tedbire esas olan hakkını, ihtiyati tedbir sebep veya sebeplerini keza davanın esası yönünden de haklılı̆̆ıı ispat etmelidir". 
eyleminin gerçekleştirildiği bir durumda, hasız rekabet eyleminin failinin dava sonuçlanıncaya kadar bu iş ürününden yararlanmaya devam etmesi de yine telafisi imkansız zararlara neden olabilecektir.

Belirtmek gerekir ki TTK m. 55'de yer verilen haksız rekabet hallerinin ekseriyetinde, ihtiyati tedbir sebeplerinin bulunduğundan bahsedilebilecektir. Zira haksız rekabete konu haklar genellikle kısa ömürlü olup, uzun süren davaları kaldıramayacak kadar geçici niteliktedirler ${ }^{16}$. Bu sebeple de haksız rekabet eyleminin yargilama boyunca devam etmesi, talepte bulunanın zararın artmasina neden olacağı gibi işletme bakımından yıkıcı sonuçlar doğurabilecektir. Dolayısıyla her somut olayda ayrıca değerlendirilmesi gerekmekle birlikte, ihtiyati tedbirin sebep unsurunun haksız rekabet hallerinde mevcut olabileceği göz ardı edilmemelidir.

Bununla birlikte özellikle haksı rekabet uyuşmazlıklarında mahkemelerin ihtiyati tedbire karar verme konusunda çekingen davrandıkları müşahede edilmektedir. Mahkemeler genellikle uyuşmazlığın yargılamayı gerektirmesi, tarafların haklılık ve haksızlı̆̆ının ancak yargılama neticesinde ortaya çıkabilecek olması nedeniyle ihtiyati tedbire sıcak yaklaşmamaktadırlar ${ }^{17}$. Bunun yanında mahkemelerce, haksız rekabet eyleminin devam etmesinin işletmeler yönünden yıkıcı etkilerinin olabileceği hususu da göz ardı edilmektedir. Nitekim İstanbul Bölge Adliye Mahkemesi 12 HD tarafından verilen kararda ${ }^{18}$, "davacının ticaret unvanına haksız tecavüz olup olmadığı yapılacak yargilama sonucunda belirlenecek olup, daval şirketin halen ticaret sicilinde tescilli bulunan unvanının kullanılmasının engellenmesi davanın taraflarının menfaat dengesine uygun düşmemektedir. Bir zarara uğraması halinde tazminini talep etme hakkı mevcuttur. Davacının talebinin haklilğı bu konudaki incelemeler tamamlandığında anlaşılabilecek olduğundan, ... davacı tarafın davanın esası bakımından haklilı̆̆ın yaklaşık ispat derecesinde ispatlanması koşulunun gerçekleşmediği belirlenmekle..." şeklinde hüküm kurularak, zarar tehlikesinin mevcut olmadığ veya zarar tehlikesi mevcut olsa dahi bunun tazminat talebi ile giderilebileceği gerekçesiyle ihtiyati tedbir kararı verilmesine gerek görülmemiştir. Gerçekten de ihtiyati tedbir konusunda taraf menfaatleri dikkate alınmalı ve karşı tarafın haklarına mümkün mertebe müdahale etmekten kaçınılarak bir karar verilmelidir ${ }^{19}$. Çünkü dava sonuçlanmadan bir davadaki haklılık durumunun ortaya çıkması mümkün değildir. Ancak bir zararın mevcut olduğu durumda tazmininin mümkün olması ve bu sebeple de ihtiyati tedbir kararının verilmemesi yerinde bir yaklaşım değildir. Zira daha önce de belirtildiği üzere haksız rekabet uyuşmazlıklarında zararın belirlenmesi çoğu zaman mümkün olmamaktadır. Bu da haksız rekabet eyleminden zarar gören kişilerin davayı kazansalar bile zararlarını karşılayamamaları sonucunu doğurmaktadır. Bu itibarla ihtiyati tedbir kararları, çoğunlukla asıl davada verilecek karardan daha önemli niteliktedir. İhtiyati tedbir kararı ile zararın artmasının önüne geçilmesi çok daha etkili bir yol olacağı gibi kanun koyucunun dürüst rekabet ortamının teminine yönelik iradesine de daha uygundur. Çünkü haksız rekabet eylemi devam ettiği sürece dürüst bir rekabet ortamının varllğından bahsedilemeyecektir.

16 Deren Yildırım (n 9) 7; Erdil (n 6) 438.

17 Erdil (n 6) 442.

18 İstanbul BAM 12 HD, E 2019/802 K 2019/660, 7.5.2019 (Pekdinçer ve Tok (n 10) 257-258.)

19 Fornage and Chaloz (n 1) 401. 


\section{IHTIYATI TEDBIRE DAYANAK OLAN HAK VE SEBEP UNSURLARINA ILIŞKIN YAKLAŞIK ISPAT KOŞULU}

İhtiyati tedbire karar verilebilmesi için tedbir talebinde bulunanın normal bir yargılamada olduğu gibi hasmına karşı maddi hukuk anlamında bir hak ileri sürmesi gerekmektedir. İhtiyati tedbir bakımından incelenmesi gereken bu şart, HMK m. 390/III'de, "davanın esast yönünden kendisinin haklllğııı...” şeklinde ifade edilmiştir. Bu şart esas itibariyle hâkimin, talep edenin ileri sürdüğü hakka bakarak haklılık öngörüsünde bulunması, diğer bir anlatımla esasa ilişkin açılacak davada talepte bulunan tarafın haklılığının ortaya çıkacağı yönündeki kanaatinin, davanın reddedilmesine olan kanaatine ağır basması olarak anlaşılmaktadır ${ }^{20}$.

İhtiyati tedbir talebinde bulunan taraf, davadaki haklılığını yaklaşık ispat ölçüsüne göre ispatlamakla yükümlüdür. Bu itibarla talepte bulunan, tedbire esas olan hakkını, ihtiyati tedbir sebeplerini ve aynı şekilde davanın esası yönünden haklılığını da yaklaşık olarak ispat etmelidir. İhtiyati tedbir yargılamasında yaklaşı ispat ölçütünün kullanılıyor olması, sadece talepte bulunanın beyanları ile yetinileceği anlamına gelmemektedir ${ }^{21}$. Talepte bulunanın delillere dayanmak suretiyle ihtiyati tedbirin şartlarının mevcut olduğunu ispatlaması da ayrıca aranmaktadır. Talepte bulunanın dayandığı deliller dolayısıyla hâkim, ispat edilmek istenen olayı muhtemel görmeli, iddia edilen olayın doğru olma ihtimalinin yanlış olma ihtimaline göre ağır bastığı kanaatine ulaşmalıdır ${ }^{22}$. Dolayısıyla mahkeme nezdinde oluşturulacak olan kanaatin somut verilere dayanması gerekliliğinin ifade edilmesi itibariyle önemlidir. Yaklaşık ispat da ancak objektif verilere dayanan, talepte bulunanın beyanlarından ibaret olmayan bilgilerin mevcut olması ihtimalinde gerçekleşecektir.

Yaklaşı ispat kuralının, özellikle ifa amaçlı ihtiyati tedbire karar verileceği hallerde farklı uygulanması gerektiği doktrinde ileri sürülmektedir. Zira bu halde aleyhine tedbir kararına hükmedilen tarafın hukuki alanına ciddi bir müdahalede bulunulmaktadır. Dolayısıyla ihtiyati tedbir taleplerinde aranan ispat derecesinin tespitinde, aleyhine ihtiyati tedbir talep edilenin hukuki alanına yapılacak müdahalenin büyüklügünün önem taşıdığ 1 ifade edilmektedir. Dolayısıyla ihtiyati tedbir kararı neticesinde karşı tarafın hakkı ne kadar tehlikeye düşecekse ispat ölçüsünün de o kadar yükselmesi gerektiği bu görüş uyarınca belirtilmektedir ${ }^{23}$. Bunun bir sonucu olarak da haksız rekabet uygulamasında olduğu gibi, ifa amaçlı ihtiyati tedbirlerin varlı̆̆ı halinde, karşı tarafın ağır zarara uğrama tehlikesi mevcut olduğundan somut olayın şartlarına göre tam ispatın da aranabileceği kabul edilmektedir ${ }^{24}$. Sonuç itibariyle ihtiyati tedbir taleplerinde aranan ispat ölçüsünün, tedbirin sonuçlarının ağırlığı ve tedbirin eski hale iade edilememesi tehlikesi ile doğru orantılı olarak tam ispata yaklaşabilecektir. Elbette ispat ölçüsü belirlenirken ihtiyati tedbir kararının talepte bulunanın asıl dava sonucunda verilecek karara ne derece yaklaştırdığı da önemli bir etken olarak karşımıza çıkmaktadır ${ }^{25}$.

20 Özekes, Medeni Usul Hukuku (n 3) 2463; Ejder Yllmaz, Hukuk Muhakemeleri Kanunu Şerhi (Yetkin 2017) 3547.

21 Özekes, Medeni Usul Hukuku (n 3) 2476; Mehmet Özdemir, Geçici Hukuki Korumalar (Adalet 2018) 91.

22 Bkz. Ankara Bölge Adliye Mahkemesi 22. HD, E 2017/283 K 2017/187, 24.02.2017 (Özdemir (n 21) 92).

23 Serdar Kale, Marka Davalarında Yargllama Usulü (Adalet 2020) 247.

24 Evrim Erişir, Geçici Hukuki Korumanın Temelleri ve İhtiyati Tedbir Türleri (Oniki Levha 2013) 218.

25 Deren Yildırım (n 9) 66. 
Bu noktada 6769 sayılı Sınai Mülkiyet Kanunu’nun ihtiyati tedbire ilişkin hükmü üzerinde de kısaca durulması yerinde olacaktır. Sınai mülkiyet haklarına tecavüzün kendine has özellikleri nedeniyle SMK m. 159'da ayrıca bir ihtiyati tedbir düzenlemesine yer verilmiştir. "İhtiyati Tedbir Talebi ve İhtiyati Tedbirin Niteliğì kenar başlıklı maddenin ilk fıkrası, "Bu Kanun uyarınca dava açma hakkı olan kişiler, dava konusu kullanımın, ülke içinde kendi sınai mülkiyet haklarına tecavüz teşkil edecek şekilde gerçekleşmekte olduğunu veya gerçekleşmesi için ciddi ve etkin çalışmalar yapıldığımı ispat etmek şartıyla, verilecek hükmün etkinliğini temin etmek üzere, ihtiyati tedbire karar verilmesini mahkemeden talep edebilir." şeklinde kaleme alınmıştır. SMK m.159/II'de ise ihtiyati tedbir türleri sayılmış olup aynı TTK m. 61'de olduğu gibi ifa amaçlı ihtiyati tedbir türlerinin yoğunlukta olduğu görülmektedir. Maddede en dikkat çeken husus, ihtiyati tedbir hak ve sebeplerinin yaklaşık ispatından bahsedilmemesidir. Gerçekten de kanun koyucu bu maddede "ispatı" aramıştır. Bu eğilimin de yukarıda açıklandığı şekliyle, ifa amaçlı ihtiyati tedbirle bozulan menfaat dengesinin sağlanması ile açıklanmasının mümkün olduğu düşünülmektedir.

\section{B. HAKSIZ REKABET UYUŞMAZLIKLARINDA IHTIYATI TEDBIR UYGULAMALARININ DEĞERLENDIRILMESi}

TTK m. 61 hükmü ile dava sonucunda tesis edilecek kararların ihtiyati tedbir yoluyla da verilebileceği kabul edildiğinden, düzenlemenin, uyuşmazlığın esasının zamanından önceçözümlenmesiyönündeki ilkenin istisnasını oluşturduğu açıkça görülmektedir. Bununla birlikte böylesi ağır ihtiyati tedbir kararının verilmesinde, tedbir talep eden ile karşı taraf arasındaki menfaat dengesinin de korunması bir zorunluluk olarak karşımıza çıkmaktadır. Bu dengenin ispat ölçüsünün ağırlaştırılmasıyla kurulabileceği savunulmakla birlikte ${ }^{26}$, mahkemelerce sıklıkla başvurulan, “uyuşmazlığın çözümünün yargılamayı gerektirmesi” nedenine dayalı tedbir taleplerinin reddedilmesinin de sakıncalı sonuçlar doğuracağı açıktır. Zira ispat ölçüsünün ağırlaştırılması bu sefer de talepte bulunanın büyük hak ihlallerine uğramasına neden olacaktır. Yaklaşık ispatın dahi çoğu zaman kanıtlanamadığının ileri sürüldügü haksız rekabet uyuşmazlıklarında, tam ispatın aranması ihtiyati tedbir uygulamasını imkansız hale getirebilecektir. Ancak ihtiyati tedbir müessesinde yer alan menfaat dengesini korumaya yönelik mekanizmaların devreye sokulması ile bu sorunların üstesinden gelinebileceği düşünülmektedir. Bu bağlamda ilk olarak ihtiyati tedbir talep edenin HMK m. 392 uyarınca teminat gösterme yükümlülüğü üzerinde durulmalıdır.

İhtiyati tedbirde teminat gösterme yükümlülüğü HMK m. 392'de, “İhtiyati tedbir talep eden, haksız çıktı̆̆ı takdirde karşı tarafin ve üçüncü kişilerin bu yüzden uğrayacakları muhtemel zararlara karşılık teminat göstermek zorundadır. Talep, resmi belgeye, başkaca kesin bir delile dayanıyor yahut durum ve koşullar gerektiriyorsa, mahkeme gerekçesini açıkça belirtmek şartıyla teminat alınmamasına da karar verebilir. Adli yardımdan yararlanan kimsenin teminat göstermesi gerekmez.” şeklinde belirlenmiştir. Bu konudaki yargı kararlarının da ihtiyati tedbirde karşı teminat gösterilmesinin zorunlu olduğu yönünde geliştiği belirtilmelidir. Karşı teminatın olmaması davalı tarafın ihtiyati tedbir sebebiyle uğrayabileceği zararların teminatsız kalması sonucunu doğuracak olup bu sonuç taraflar arasındaki 
menfaat dengesine de aykırılık teşkil edecektir ${ }^{27}$. Karşı teminat ile haksız rekabet eyleminde bulunduğu ileri sürülen tarafa yönelik ihtiyati tedbir talebi neticesinde meydana gelecek hak kayıplarının da bu sayede tazmini mümkün olacağı gibi, ihtiyati tedbir talebinde bulunan bakımından da bir külfet getirilmek suretiyle tarafların menfaatleri dengelenmeye çalışılmaktadır.

Taraflar arasındaki menfaat dengesini sağlayan bir diğer mekanizma da haksız rekabet hukuku hükümlerinde öngörülmüsstür. TTK m. 59'da yer alan "Mahkeme, davayı kazanan tarafın istemiyle, gideri haksız çıkan taraftan alınmak üzere, hükmün kesinleșmesinden sonra ilan edilmesine de karar verebilir. İlanın şeklini ve kapsamın mahkeme belirler." düzenlemesi ile, davada haklı çıkan tarafın istemi üzerine kararın gazetede ilan edilebileceği kabul edilmiştir. Böylece kararın büyük kitlelere duyurulması sağlanmış olmakta ve bu vesileyle de ilgili tarafın haklılı̆̆ı ortaya konulmaktadır. $\mathrm{Bu}$ hüküm özellikle yanlış veya yanıltıcı beyanların düzeltilmesi şeklinde verilen ihtiyati tedbir kararları bakımından önemlidir. Zira ihtiyati tedbir yoluyla yanlış veya yanıltıcı beyanların düzeltilmesi halinde talepte bulunanın talebinin geçici değil kesin bir biçimde yerine getirildiğinden bahsedilebilecektir ${ }^{28}$. Böylece talepte bulunan ancak dava sonucunda ulaşabileceği sonuca henüz davanın başında ulaşarak yargılamadan beklediği faydayı da sağlamış olacaktır. Ancak TTK m. 59'da yer alan ilan müessesesi sayesinde, davanın reddi durumunda kararın ilanı yaptırılarak, ifa amaçlı ihtiyati tedbir kararının sakıncalı sonuçları ortadan kaldırılmış olacaktır. Masrafları davada haksız çıkan tarafça karşılanacak gazete ilanları ile, ihtiyati tedbirin yanlışlı̆̆ da büyük kitlelere duyurulmuş olacaktır.

\section{SONUÇ}

Haksız rekabet hukukunda ihtiyati tedbir kurumunun önemi, haksız rekabet hükümleri ile korunan menfaatlerin nitelikleri gereği oldukça önemlidir. Bu öneme binaen kanun koyucu ayrı bir hüküm ile haksız rekabet hukukunda ihtiyati tedbir müessesesini düzenlemiştir. İhtiyati tedbirlerin ifa amacına yönelik olması, uyuşmazlıkların esasının zamanından önce çözümlenmesi sonucunu doğurabilecek nitelikte olmakla birlikte, haksız rekabete konu hakların çoğunlukla kısa ömürlü ve uzun süreli davaları kaldıramayacak nitelikte olmaları nedeniyle ifa amaçlı ihtiyati tedbirler bir

27 “Patentin hükümsüzlüğ̈̈ davasında, taraf teşkilinin sağlanması ve yargılama sırasında taraf değişikliği nedeniyle yargılamanın uzamaması yönünden, dava konusu tescil belgesinin devrinin önlenmesi yönünde tedbir kararı verilmesi, usul ekonomisi ve yargılamanın hızlı bir şekilde sonuçlandırılması yönünden yerindedir, ancak devrin önlenmesi kararı, davalı tescil sahibinin tasarruf yetkisini kısıtladığından, davalının olası zararları yönünden teminat alınması gerektiğinden, davalı vekilinin istinaf başvurusunun kısmen kabulüne, kısmen reddine, mahkemenin 15/06/2021 tarihli kararının kaldırılmasına, davalı vekilinin itirazının kısmen kabulü ile, mahkemenin 09.04.2021 tarihli tedbir kararının kaldırılmasına, davacı tarafça 20.000 TL nakdi teminat yahut ayn miktarda kesin ve süresiz teminat mektubu ibraz edildiğinde, dava konusu patent tescil belgesinin devir ve temlikinin önlenmesi yönünde tedbir konulmasına karar verilmiștir." Karar için bkz. İstanbul BAM 16 HD, E 2021/1462 K 2021/1587, 23.09.2021 (Lexpera Bilgi Bankası). Benzer bir başka kararda ise “...davact tarafın İhtiyati tedbire dair yaklaşık ispat şartını yerine getirdiğinin kabulünün isabetli olacağı kanaatine varılmıştır. Ancak, ayn yasanın 392. maddesi kapsamında teminatsız İhtiyati tedbir kararı verilmesi talebinde isabet görülmemiştir. Şöyle ki, yasada, İhtiyati tedbir talep edenin haksız çıktığı takdirde karşı tarafın ve üçüncü kişilerin bu yüzden uğrayacakları muhtemel zararlara karşılık teminat göstermek zorunda olacağına yer verilmiştir. Yasanın iş bu konudaki düzenlemesi emredici niteliktedir." şeklinde hüküm tesis eden istinaf mahkemesi, ihtiyati tedbirdeki teminatın zorunluluğunu açıkça ortaya koymuştur. Karar için bkz. İstanbul BAM 17. HD, E 2020/2067 K 2020/2005, 12.11.2020 (Lexpera Bilgi Bankası).

Deren Yildırım (n 9) 90. 
zorunluluk olarak karşımıza çıkmaktadır. Mahkemelerce ihtiyati tedbire karar verilmesinde çekingen davranılması haksız rekabet uyuşmazlıklarında, davacı tarafın telafisi mümkün olmayan zararlara uğramasına neden olmaktadır. Elbette ifa amaçlı ihtiyati tedbirlerin söz konusu olması dolayısıyla ispat ölçütünün daha yüksek belirlenmesi gerektiği savunulmaktaysa da bu durum ihtiyati tedbir uygulamasının önünde bir engel olarak görülmemelidir. Zira haksız rekabet hukuku ve ihtiyati tedbir kurumu özelinde menfaat dengesini sağlamaya yönelik birçok mekanizma mevcuttur.

\section{KAYNAKÇA}

Deren Yıldırım N, Haksız Rekabet Hukuku ile Fikri ve Sinai Mülkiyet Hukukunda İhtiyati Tedbirler (Alkım 1999).

Erdil E, Haksız Rekabet Hukuku (Seçkin 2020).

Erişir E, Geçici Hukuki Korumanın Temelleri ve İhtiyati Tedbir Türleri (Oniki Levha 2013).

Fornage A C ve Chabloz I, 'Remarques Liminaires Aux Articles 9 a 11 LCD’ in Vincent Martenet and Pascal Pichonnaz (eds), Commentaire Romand (Helbing Lichtenhahn, 2017).

Kale S, Marka Davalarında Yargılama Usulü (Adalet 2020).

Keskinci D, 'Haksız Rekabet Yargılama Hukukunda İfa Amaçlı İhtiyati Tedbirler' (2013) 2(2) Zirve Üniversitesi Hukuk Fakültesi Dergisi 145-154.

Korkmaz R, Haksız İhtiyati Tedbir ve İhtiyati Hacizden Kaynaklanan Tazminat Davası (Oniki Levha 2020).

Kuru B, Arslan R ve Ejder Y, Medeni Usul Hukuku (Yetkin 2013).

Nomer Ertan N F, Haksız Rekabet Hukuku (Oniki Levha 2016).

Özdemir M, Geçici Hukuki Korumalar (Adalet 2018).

Özekes M, 'Fikir ve Sanat Eserleri Hukukunda İhtiyati Tedbir' (2002) 4(2) Dokuz Eylül Üniversitesi Hukuk Fakültesi Dergisi 89-138

Özekes M, 'Geçici Hukuki Koruma’ iç Hakan Pekcanıtez (edr) Medeni Usul Hukuku (Oniki Levha 2017).

Pekdinçer R T ve Tok O A, İsviçre Hukuku ile Mukayeseli Türk Haksız Rekabet Hukuku Mevzuatı, (Seçkin 2019).

Tunç Yücel M, 'Haksız Rekabet Hukukunda Teminat Amaçlı İhtiyati Tedbirler' iç Prof. Dr. Ergun Önen'e Armağan (Alkım 2003) 417-430.

Yılmaz E, Hukuk Muhakemeleri Kanunu Şerhi (Yetkin 2017). 